\title{
THE EFFECT OF IRRIGATION DOSES ON THE PRODUCTIVITY OF Citrus clementina variety "Fina Berkane", A VARIETY OF CLEMENTINE PRODUCED IN TRIFFA PLAIN, NORTH EASTERN MOROCCO
}

\author{
Anwar Bousamid ${ }^{1}$, Btissam Mzabri ${ }^{1}$, Jamal Benyazid ${ }^{2}$, Zerhoune Messaoudi $^{3}$, \\ Abdelmajid Belabed ${ }^{1}$, Abdelbasset Berrichi ${ }^{1}$
}

\footnotetext{
${ }^{1}$ Laboratory of Agricultural Production improvement, Biotechnology and Environment, Faculty of Science, Mohammed First University of Oujda, Morocco

${ }^{2}$ Laboratory of Biochemistry and Biotechnologies, Mohamed first University, Faculty of Sciences, Oujda, Morocco

${ }^{3}$ National School of Agriculture- Meknes, Morocco
}

Received - June 04, 2021; Revision - July 30, 2021; Accepted - August 11, 2021

Available Online-August 30, 2021

DOI: http://dx.doi.org/10.18006/2021.9(4).432.438

KEYWORDS
Water stress
Fina Berkane
Plain of Triffa
Yield
Fruit size
Fruit quality

\begin{abstract}
Morocco is a Mediterranean country with an economy based on exporting agricultural products mainly to Europe. However, the ongoing climate change characterized by the frequency and the intensity of drought, along with the regularity of the rainfall is undeniably affecting the productivity of major agricultural products in Morocco. Citriculture is one of the key pillars of agricultural products in Moroccan conditions and the productivity of citriculture is tightly related to water management. To reduce this dependency under climatic change, a pilot study, over three years, has been launched to assess the effect of water stress on the production of clementine (Citrus clementina 'Berkane Clementine'). This study was carried out on the clementine, variety "Fina Berkane" at the Triffa plain, Northeastern Morocco. This variety was grafted on Volkameria rootstock with a density of $3 \mathrm{~m}$ x $6 \mathrm{~m}$. Experimental variety was planted during October 2012, in loam-clay soil equipped with a drip irrigation system. Four doses of water irrigation $(60 \%, 80 \%, 100 \%$, and the conventional irrigation dose $\geqslant 120 \%$ ) were tested based on the real water demand of the studied plant. Throughout the three-year monitoring, the effect of used water amount on the various parameters including yield, fruit size, and fruit quality have been studied. Results of the study revealed that the treatment $100 \%$ ETc provided a high number of fruits, yield, and a good quality ratio. It was also well reported that adopting a dose of $80 \%$ ETc could save a significant amount of irrigation water (more than $40 \%$ ETc) compared to the conventional irrigation dose $(\geqslant 120 \%$ ETc) without significantly affecting either the yield or the desired caliber profile (marketable standard).
\end{abstract}

* Corresponding author

E-mail: anwarbousamid@gmail.com (Anwar Bousamid)

Peer review under responsibility of Journal of Experimental Biology and Agricultural Sciences.

Production and Hosting by Horizon Publisher India [HPI] (http://www.horizonpublisherindia.in/).

All rights reserved.
All the articles published by Journal of Experimental Biology and Agricultural Sciences are licensed under a Creative Commons Attribution-NonCommercial 4.0 International License Based on a work at www.jebas.org.

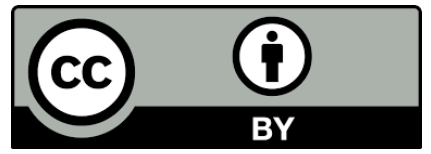




\section{Introduction}

The citrus sector occupies a preeminent place in Moroccan agro and socio-economic development and constitutes one of the most important branches of the national economy (MAPM, 2016). The Triffa plain (Northeast region of the country) renowned for its famous clementine "FinaBerkane" variety (Anonymous, 2014), is a flagship product of the region, and undeniably one of the best varieties of Moroccan clementine orchards. "Fina Berkane" is well recognized for its organoleptic qualities, particularly in European markets (Anonymous, 2010).

In the plains of Triffa, the agricultural sector provides a gross annual income of nearly $6 \mathrm{M}$ Dollars and creates more than two million jobs per year on farms and packaging stations, in addition to its foreign exchange contribution (Anonymous, 2020). However, in recent years, the area has experienced harsh climatic conditions marked with a low rainfall affecting the dams and reservoirs of the Moulouya hydraulic complex (Anonymous, 2017). The scarcity of irrigation water is one of the main factors causing the regression in productivity and the decline of operated citrus orchards (Disket et al., 2017). Currently, water resources for irrigation in the region are under pressure due to the increasing demand, frequency, and intensity of drought events due to climate change. Rational water management is therefore essential to minimize the pressure on these resources and improve the production quantity and quality.

Studies on the behavior of Clementine in the Triffa Plain concerning irrigation doses are very limited. In this context, this work investigates the effect of irrigation doses on the yield, size, and quality of the "Fina Berkane" variety grafted on the Volkameriana through a comparative study based on evapotranspiration data method (crop transpiration and soil evaporation) (FAO, 2021).

\section{Materials and methods}

\subsection{The study site}

This study was carried out during three consecutive agricultural seasons (2016-2017, 2017-2018, and 2018-2019) on 9 years old Clementine "Fina Berkane" grafted on the Volkameriana rootstock. The study site is a private orchard called "INAGRI" with an area of 245 hectares, in the province of Berkane, northeast of Morocco (North $35^{\circ} 00^{\prime} 05.7$ "; West $2^{\circ} 11^{\prime} 42.3^{\prime \prime}$; altitude of $119 \mathrm{~m})$. The climate of the study area is Mediterranean, semi-arid, characterized by an average temperature between $17.1-20.5^{\circ} \mathrm{C}$, and a very irregular rainfall ranged between 200 and $350 \mathrm{~mm} /$ year. The soil type is isohumic developed on a calcareous crust, rich in organic matter (ENAM, 2017).

\subsection{Orchard management}

\subsubsection{Planting system}

The study plot is approximately nine ha, planted in 2012, with a planting distance of $6 \mathrm{~m}$ between rows and $3 \mathrm{~m}$ within rows, which is equivalent to 556 trees per hectare.

\subsubsection{Irrigation system}

The orchard uses an irrigation system based on localized drips. Each planting line has two booms of $16 \mathrm{~mm}$ in diameter each, fitted with integrated self-regulating Uni-ram drippers, uniformly distributed $(0.75 \mathrm{~m})$ on the boom and delivering 2.45 Liter per hour. Each tree receives about $9.8 \mathrm{~L} / \mathrm{h}$ water ensured by four drippers. However, the surface affected by each dripper is $6 \mathrm{~m} \times 0.75 \mathrm{~m}=4.5 \mathrm{~m}^{2}$. The hourly rainfall is the water supply capacity on the irrigation system. It is expressed in $\mathrm{mm} /$ hour and it depends on the adopted system developed by Boyer et al. (2013) as mentioned below:

Hourly rainfall $(\mathrm{mm} / \mathrm{h})=$ Dripper flow rate $(\mathrm{L} /$ hour $) /$ device $\operatorname{mesh}(\mathrm{m} 2)=0.54 \mathrm{~mm} / \mathrm{h}$

\subsection{The objectives of the trial}

This work is a part of the "Rational irrigation of citrus fruits in the sedimentary environment of eastern Morocco" project. The main objective of the study is to assess the real water needs of the clementine tree in the Triffa Plain and to study the behavior of this species in response to different irrigation regimes during three successive agricultural seasons i.e. 2016-2017, 2017-2018, and 2018- 2019. The trial involved 100 trees, following a completely random block experimental setup with three replicates per dose. The preliminary survey carried out among citrus farmers in the study area allows us to test four irrigation doses i.e. dose 1 (farmer dose): $\geqslant 120 \%$ ETc, dose 2: 100\% ETc, dose 3: 80\% ETc, and dose 4: $60 \%$ ETc. The entire block was spread over 4 rows or 25 trees per irrigation dose.

\subsection{Determination of the irrigation dose}

The water requirements of citrus trees are determined by estimating the potential of evapotranspiration (ETc), which is established daily according to the method described in FAO's irrigation and drainage paper (No. 56) (Allen et al., 1998):

$$
\operatorname{ETc}(\mathrm{t})=\operatorname{Kc} \times \operatorname{ETo}(\mathrm{t})
$$

Where;

t: time period; d (in days); ETo: reference of evapotranspiration $(\mathrm{mm} / \mathrm{d})$ calculated from the universal formula PENMANMONTEITH (Allen et al., 1998); Kc: coefficient of cultivation, which is the ratio between culture evapotranspiration (ETc) and potential evapotranspiration (ET0). 
It incorporates the effects of the four main characteristics that distinguish culture from the reference culture which are crop height, soil surface resistance - vegetation, albedo, soil evaporation (Allen et al., 1998). Factors affecting the value of $\mathrm{kc}$ are characteristics of the crop, the dates of planting or sowing, the rate of its development and the duration of its vegetative cycle, and the climatic conditions.

To take into account, the surface of the ground covered by the foliage, the ETc equation becomes as follows:

$$
\text { ETc }(t)=K c \times \text { ETo }(t) \times K r
$$

With $\mathrm{Kr}$ is the reduction coefficient used to consider the soil covered by the tree (C.O.I, 1997), and it can be calculated by the following method:

$$
\mathrm{Kr}=2 * \mathrm{Sc} / 100
$$

Where: $\mathrm{Sc}=\pi * \mathrm{D} 2 * \mathrm{~N} / 400, \mathrm{D}$ is the average of the canopy diameters (m) and $\mathrm{N}$ is the planting density (tree/ha). In this study, the $\mathrm{Kr}$ values are represented in Table 1.

Table 1 Calculation of the $\mathrm{Kr}$ for the current study

\begin{tabular}{|cc|}
\hline \multicolumn{2}{|c|}{ Kr test } \\
\hline $\mathrm{D}$ & $2.48 \mathrm{~m}$ \\
\hline $\mathrm{N}$ & 555.55 trees \\
\hline $\mathrm{Sc}=\pi * \mathrm{D} 2 * \mathrm{~N} / 400$ & $26.82 \mathrm{~m}^{2}$ \\
\hline $\mathrm{Kr}=2 * \mathrm{Sc} / 100$ & $0.54 \mathrm{~m}^{2}$ \\
\hline
\end{tabular}

The $\mathrm{ET}_{0}$ is the reference of evapotranspiration, precipitation, and other climatic parameters, which are determined from the climatic data recorded by the PROAGOR domain weather station located in Laatamna - Berkane.

\subsection{Observations}

\subsubsection{Yield and number of fruits}

Harvesting of citrus fruit from Triffa plain carried out between mid-Octobers and early November. During this period of each season, the yield of each tree was determined in weight $(\mathrm{kg})$ and the number of fruits.

\subsubsection{Fruit size}

The size of the fruit is considered among the most important parameters that determine the value of the fruit in the international market. Governments, producers, traders, importers, exporters, and other international organizations use the UNECE FFV-14 standard for the marketing and commercial quality control of citrus fruits (Anonymous, 2017a). Its purpose is to define the qualities that citrus fruits must exhibit after conditioning and packaging (Anonymous, 2017a). Commercially, sizes 1, 2, and 3 have the highest economic value (Table 2), followed by size 4, while sizes 5 and 6 represent the least market value (Anonymous, 2021).

Table 2 Scale of citrus fruit sizes according to the UNECE standard FFV-14(UNECE Standard FFV-14, 2017a)

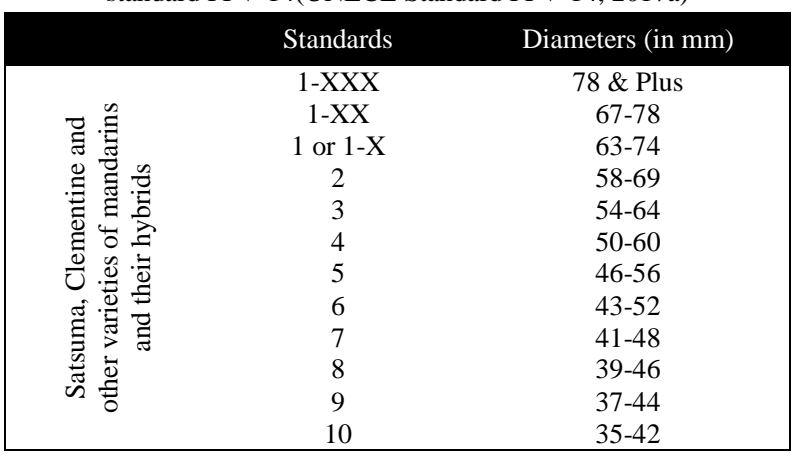

Fruit size was determined after harvest using a digital caliper. Fifty fruits per irrigation dose were taken at random to see the effect of the applied irrigation regime on the final fruit size.

\subsubsection{Organoleptic qualities of the fruits}

Fruit quality is an important factor in assessing the nutritional value and market value of citrus fruits, whether for fresh consumption or processing into juice. The qualitative characteristics of the fruits include the juice content (\%), the acidity $(\mathrm{g} / \mathrm{l})$, and the sugar rate (rate of soluble extract TSS) $\left({ }^{\circ}\right.$ Brix). They were determined at harvest with samples of at least 12 fruits per tree tested according to the procedures described by González Sicilia (1951).

\subsection{Data analysis}

The data collected on the yield parameters and the quality parameters were subjected to analysis of variance (ANOVA), followed by the analysis of means to show significant differences using $\mathrm{S}-\mathrm{N}-\mathrm{K}$ post-hoc test at 0.05 threshold value (Gomez \& Gomez, 1984).

\section{Results and Discussion}

\subsection{The effect of irrigation doses on yield and number of fruits}

Regarding the number of fruits, the results revealed non-significant differences between the irrigation doses in the first two seasons (2016-2017 and 2017-2018). While significant differences between various tested doses $(\mathrm{P}<0.05)$ were detected in the third season (2018/2019) (figure 1). For 60\% Etc dose, the maximum number of harvested fruits per tree in three successive agricultural seasons i.e. 2016-2019 was 696, 809, and 494 respectively. While during the first season $(2016 / 2017)$, the doses $\geqslant 120 \%$ ETc, $100 \%$ ETc, 
and $80 \%$ Etc resulted in a low number of fruits per tree with an average of 599, 650, and 550 respectively. The high number of fruits at the $60 \%$ ETc dose could be due to moderate water stress which favors the flowering rate and consequently the number of hanging fruits.

From the analysis of results presented in figure 2, it is clear that the yield of "FinaBerkane" is slightly affected by the irrigation doses. The applied irrigation doses did not show any significant effect on the yield of Clementine during the last two seasons (2017/2018 and 2018/2019). The stressful dose (60\% ETc) recorded the lowest yield for both seasons with respective averages of 53.5 and $39.7 \mathrm{~kg}$ per tree.

In the first season (2016-2017), the trees responded differently to different irrigation doses applied. These responses were significant for $60 \%$ Etc dose with a production not exceeding $39.3 \mathrm{~kg} / \mathrm{tree}$. While the doses $\geqslant 120 \%$ ETc, $100 \%$ ETc, and $80 \%$ Etc produced 51.4, 51.6, and $49.9 \mathrm{~kg} /$ tree respectively. Hendre et al. (2020) reported similar results, of reduced yield and fruit load following the application of water stress, for sweet oranges. Other studies carried out by Cheng et al. (2021) on cotton and Goramnagar et al. (2018) on the acid Lime also indicated a significant increase in yield when increasing irrigation doses.

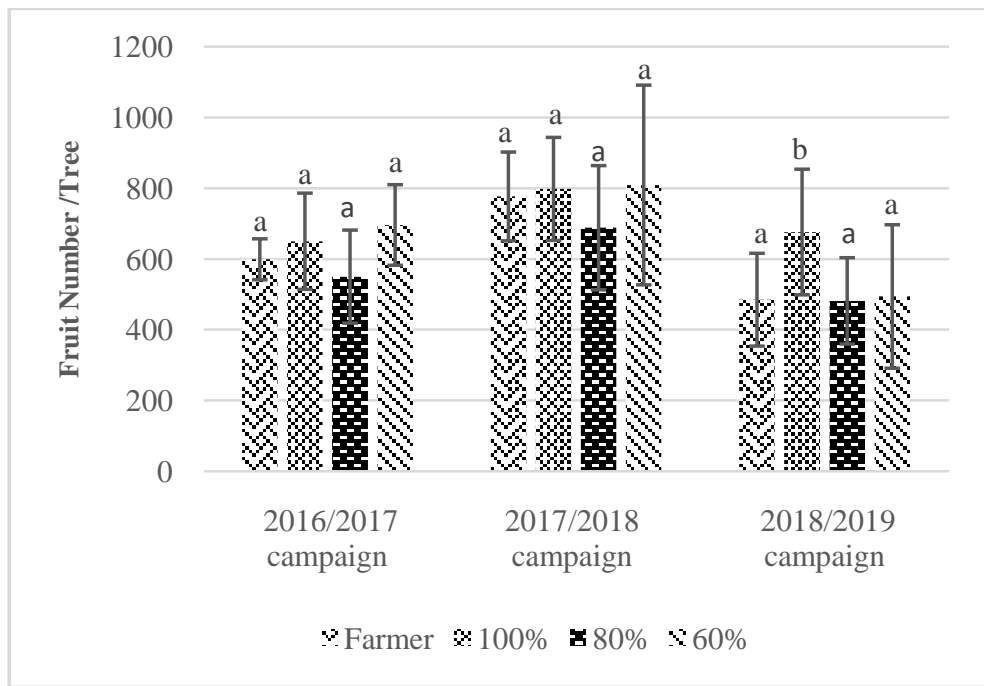

Figure 1 Effect of irrigation doses on the number of fruits per tree

(**values followed by the same letter are not significantly different according to the S-N-K test at $5 \%$ )

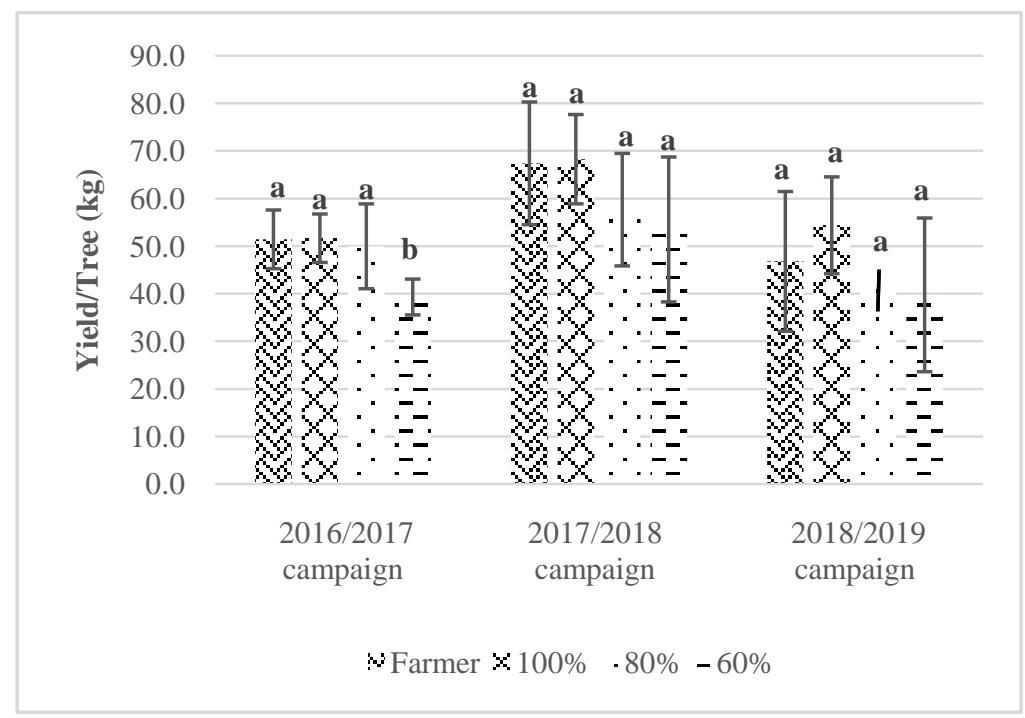

Figure 2 Effect of irrigation doses on yield per tree in $\mathrm{kg}$

(** values followed by the same letter are not significantly different according to the $\mathrm{S}-\mathrm{N}-\mathrm{K}$ test at $5 \%$ ).

Journal of Experimental Biology and Agricultural Sciences http://www.jebas.org 


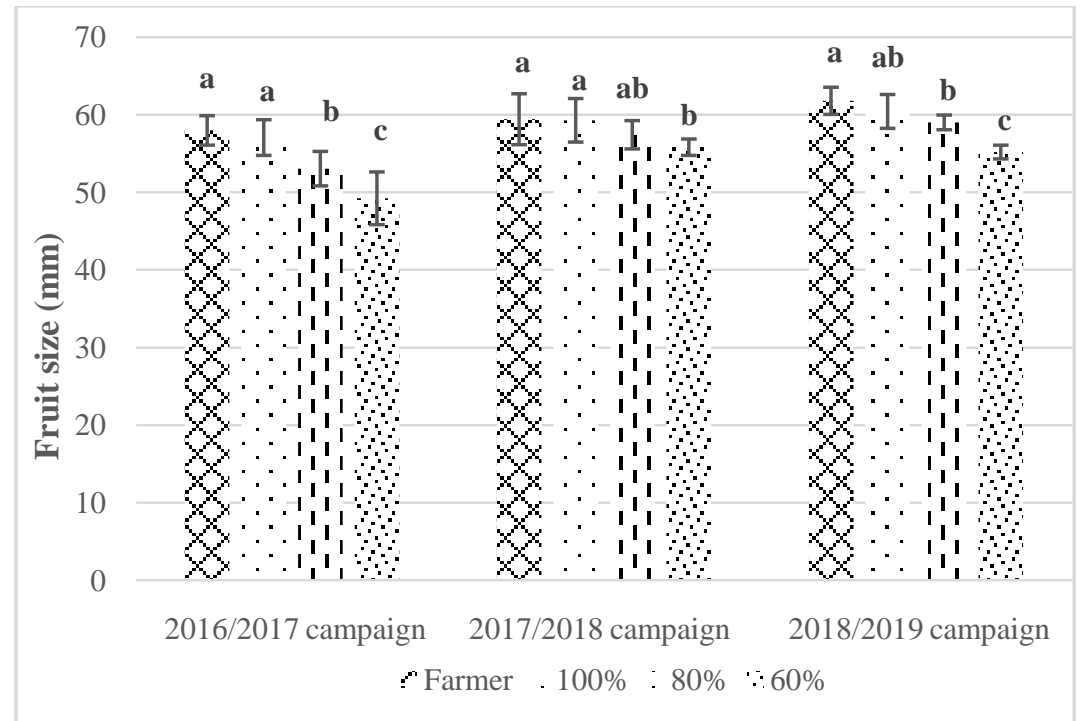

Figure 3 Effect of irrigation doses on final fruit size

(** values followed by the same letter are not significantly different according to $\mathrm{S}-\mathrm{N}-\mathrm{K}$ test at $5 \%$ ).

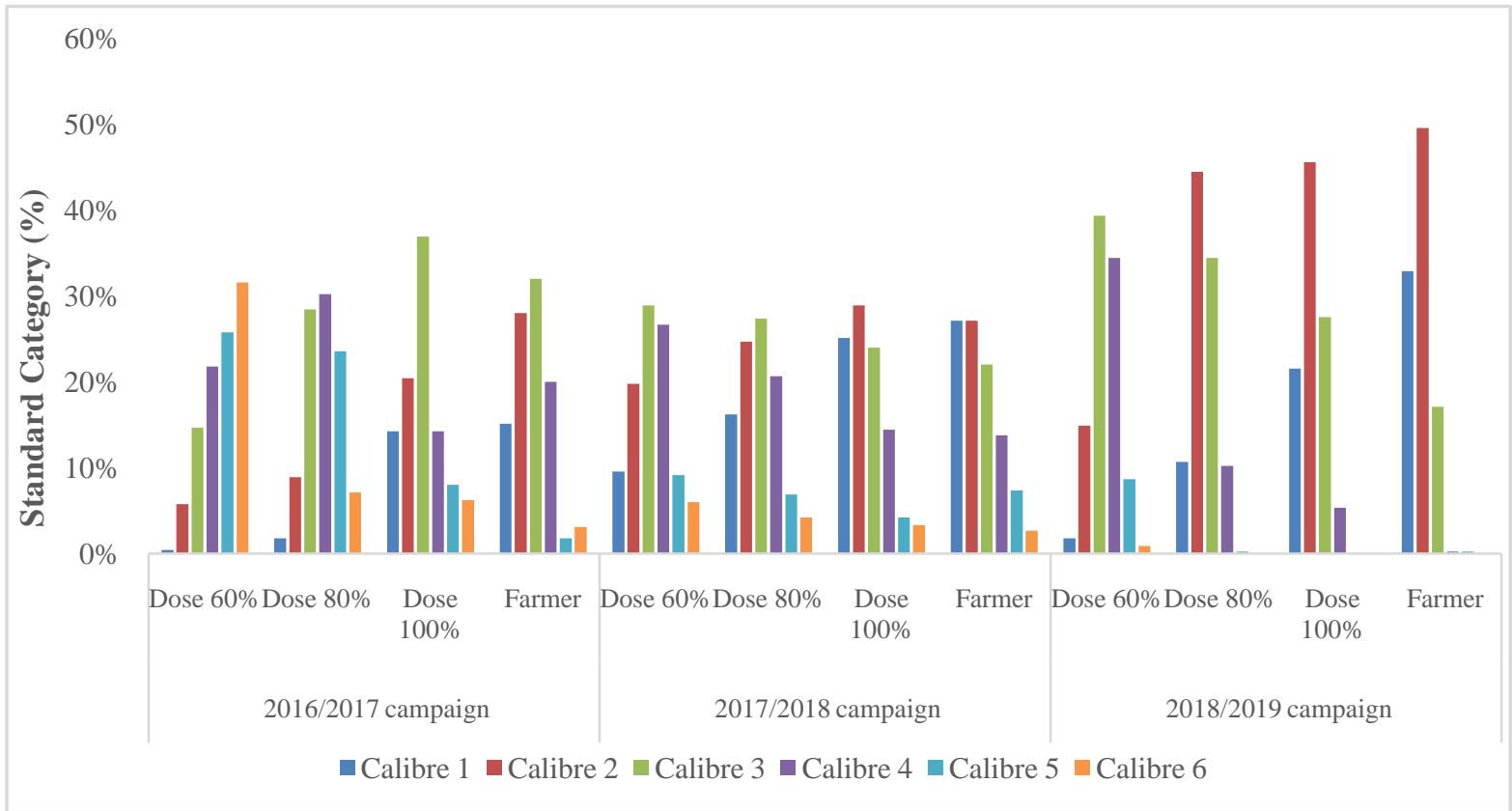

Figure 4 Effect of irrigation doses on different standard (caliber) categories of citrus fruits

\subsection{The effect of irrigation doses on fruit size}

The increase in average fruit size was significantly affected by irrigation doses (Figure 3). This effect was more pronounced during the first season (2016-2017), probably due to the low fruit load per tree. Generally, the fruit sizes were positively correlated with the irrigation doses. The high doses $(100 \%$ ETc and $\geqslant 120 \%$ ETc) provided the highest fruit sizes, and the low doses (80 and $60 \% \mathrm{ETc}$ ) recorded the lowest fruit sizes respectively.
For the commercial fruit size, the results showed that this parameter is improved by increasing the irrigation dose (Figure 4). The evaluation of fruits size percentage under various irrigation treatments indicated that the best marketable fruit sizes (cal.1, cal.2, and cal.3) were observed for $100 \% \mathrm{ETc}, \geqslant 120 \% \mathrm{ETc}$, and $80 \%$ ETc doses respectively. While the stressful dose (60\% ETc) was dominated by small calibers (cal. 4, cal. 5, and cal. 6), which have a low marketable value for export. Similarly, Mota et al. (2018) recorded that Chestnut fruit size was improved with 
Table 3 Effect of irrigation doses on different parameters of fruit qualities

\begin{tabular}{|c|c|c|c|c|}
\hline Seasons & Dose & Juice (\%) & $\operatorname{TSS}\left(\operatorname{Brix}^{\circ}\right)$ & Acidity $(\mathrm{g} / \mathrm{l})$ \\
\hline \multirow{4}{*}{$2016 / 2017$} & $\geqslant 120 \%$ ETc & $61.80^{\mathrm{a}} \pm 4.39$ & $11.20^{\mathrm{b}} \pm 0.72$ & $6.33^{\mathrm{a}} \pm 0.99$ \\
\hline & $100 \% \mathrm{ETc}$ & $56.16^{\mathrm{b}} \pm 2.19$ & $11.74^{\mathrm{a}} \pm 1.36$ & $5.53^{\mathrm{b}} \pm 1.48$ \\
\hline & $80 \%$ ETc & $51.74^{\mathrm{c}} \pm 6.20$ & $11.87^{\mathrm{a}} \pm 1.73$ & $5.13^{c} \pm 0.98$ \\
\hline & $60 \%$ ETc & $50.00^{\mathrm{c}} \pm 0.59$ & $12.18^{\mathrm{a}} \pm 1.60$ & $5.15^{\mathrm{c}} \pm 3.21$ \\
\hline \multirow{4}{*}{$2017 / 2018$} & $\geqslant 120 \% \mathrm{ETc}$ & $40.81^{\mathrm{a}} \pm 4.26$ & $10.57^{b} \pm 0.83$ & $2.82^{\mathrm{a}} \pm 0.67$ \\
\hline & $100 \% \mathrm{ETc}$ & $40.54^{\mathrm{a}} \pm 2.50$ & $11.15^{\mathrm{b}} \pm 0.50$ & $2.77^{\mathrm{a}} \pm 0.51$ \\
\hline & $80 \%$ ETc & $39.24^{\mathrm{a}} \pm 3.44$ & $11.46^{\mathrm{ab}} \pm 0.87$ & $3.7^{\mathrm{b}} \pm 0.77$ \\
\hline & $60 \%$ ETc & $37.36^{\mathrm{a}} \pm 2.32$ & $12.05^{\mathrm{a}} \pm 0.61$ & $3.71^{\mathrm{b}} \pm 0.65$ \\
\hline \multirow{4}{*}{$2018 / 2019$} & $\geqslant 120 \% \mathrm{ETc}$ & $36.3^{\mathrm{ab}} \pm 2.61$ & $10.53^{\mathrm{a}} \pm 0.87$ & $7.75^{\mathrm{a}} \pm 2.32$ \\
\hline & $100 \%$ ETc & $38.6^{\mathrm{a}} \pm 3.25$ & $10.07^{\mathrm{a}} \pm 0.40$ & $8.91^{\mathrm{a}} \pm 2.08$ \\
\hline & $80 \%$ ETc & $35.16^{\mathrm{b}} \pm 1.81$ & $10.91^{\mathrm{a}} \pm 0.64$ & $7.77^{\mathrm{a}} \pm 2.76$ \\
\hline & $60 \%$ ETc & $34.13^{b} \pm 2.78$ & $10.84^{a} \pm 0.73$ & $7.03^{\mathrm{a}} \pm 2.50$ \\
\hline
\end{tabular}

**values following by similar letters are not significant according to the S-N-K test at $5 \%$.

increasing irrigation doses. Other studies on Kinnow Mandarin (Vijaya et al., 2017), Mosambi Sweet Orange (Ghosh \& Pal, 2016), and Valencia orange (El-Sayed \& Ennab, 2013) also suggested that the size of the final fruit is proportional to the irrigation doses.

\subsection{Effect of irrigation doses on fruit quality parameters}

According to the results presented in table 3, the "Fina Berkane" variety expressed different responses to different irrigation treatments. The response was positive for the juice content, and the highest values were reported for the highest doses viz., $\geqslant 120 \%$ ETc, and $100 \%$ ETc. These results are in line with the findings of Panigrahi \& Srivastava (2017) in citrus. The high juice contents dilute the sugar concentrations (TSS) in the fruits. However, the high values in sugar level (TSS) with a lower acidity of the juice were observed for the stressful doses (60\% ETc and $80 \%$ ETc). This high TSS ratio with low acidity is explained by a large conversion of acids to sugars in the bags of dehydrated juice (Huang et al, 2000). These results are in agreement with the findings of Mota et al. (2018), Panigrahi et al. (2012), and Beniken et al. (2008).

\section{Conclusion}

Over $70 \%$ of the world's fresh water is used for irrigation. Finding an efficient irrigation model becomes an urgent need within the context of climate change. In Morocco, irrigation is one of the most important technical issues facing citrus growers. Therefore, this work intended to investigate the effect of reduced irrigation water on the fruit yield, size, and quality of the "Fina Berkane" variety during three agricultural seasons in the open field. Results of the current study revealed a significant effect of irrigation does on the fruit yield and quality. The best irrigation treatment (100\% ETc) provides a high yield, a good caliber profile, and the desired quality ratio. This study demonstrated that $80 \%$ Etc allows a $20 \%$ reduction in the irrigation dose without affecting the yield, fruit quality, and desired size of citrus fruits. Results of the study recommend and urge the citrus farmers to adopt $80 \%$ ETc dose to significantly reduce water demand for irrigation and ultimately increase the operated citrus orchards in the Triffa plain.

\section{Acknowledgements}

The corresponding author is thankful to the head of the farm, as well as the technical staff for the help and support on the field, and the lab staff for soil analysis at the National Agricultural School of Meknes (Morocco).

\section{Conflict of interest}

The authors declare no conflict of interest

\section{References}

Allen G, Pereira S, Raes D, Smith M (1998) Crop evapotranspiration. Guideline for computing crop water requirements. Irrigation and Drainage paper 56. FAO.Rome.

Anonymous (2010) La clémentine de Berkane protégée. Fellahtrade. Agriculture du maghreb.

Anonymous (2014) L'outil de production KINI CITRUS. Groupe canavese.

Anonymous (2017) Agrumes: Une production prévisionnelle de 290000 T à berkane. AgriMaroc.ma avec MAP. 
Anonymous (2017a) Norme CEE-ONU FFV-14 concernant la commercialisation et le contrôle de la qualitécommerciale des Agrumes. 2017 Édition. Nations Unies. New York et Genève.

Anonymous (2020) Agrumes: une production de 415.240t prévue dans le périmètre de la Moulouya. MapOujda.

Anonymous (2021) RNM. Le Réseau des Nouvelles des Marchésdélivre aux professionnels de l'agro-alimentaire des informations sur les prix moyens, cours et cotations des fruits et légumes et d'autresproduits frais périssables.

Beniken L, Benazouz A, Talha A, Beqqali M (2008) Effet de la dose d'irrigation sur les agrumes: cas de la variété Navel greffé sur citrange Troyer sur un sol sableux dans le site d'ElMenzeh (Gharb, Maroc). Al Awamia, Pp. 123-124.

Boyer I, Charton P, Cordier S, Gontard F, Molle B, Mazollier C Terrentroy A (2013) L'irrigation goutte à goutte en arboriculture et culture maraîchère. L'eau fertile.

Cheng M, Wang H, Fan F, Zhang S, Wang Y, Li Y, Sun X, Yang L, Zhang F (2021) Water productivity and seed cotton yield in response to deficit irrigation: A global meta-analysis. Agricultural Water Management. Volume 255.

COI (1997) Encyclopédie Mondiale de l'Olivier, Chapitre 4, Ed. Plaza and Janéf F.A. Pp.479.

Disket D, Parshant B, Stanzin D, Preeti Ch, Kiran K, Mahender S (2017) Effect of Deficit Irrigation Scheduling on Yield and Quality of Kinnow Mandarin Fruits. International Journal of Current Microbiology and Applied Sciences 6(7): 261-269.

El-Sayed SA, Ennab HA (2013) Effect of different levels of irrigation water and nitrogen fertilizer on vegetative growth, yield and fruit quality of valencia orange trees. Minufiya Journal of Agriculture Research 383(2): 761 - 773.

ENAM (2017) Département des Sciences du Sol. Ecole Nationaled'Agriculture ENAM. Meknès. Maroc.

FAO (2021) Besoinseneaud'irrigation. AQUASTAT Systèmed'informationmondial de la FAO sur l'eau et l'agriculture.

Ghosh SN, Pal PP (2016) Effect of basin versus drip irrigation on quality production in Mosambi sweet orange. Journal of Horticultural Sciences 5: 25-29.
Gomez KA, Gomez AA (1984) Statistical Procedures for Agricultural Research. John Wiley and Sons, New York.

González-Sicilia E (1951) Características de los frutos de algunasvariedades de agrios. Boletin INIA 23, 135-209.

Goramnagar HB, Nagre PK, Munnarwar SR, Tiwari VA (2018) Effect of Micro-irrigation and Fertigation on Fruit Yield of Acid Lime (Citrus aurantifolia). PKV Research Journal. Vol. $42(1)$.

Hendre PD, Ranpise SA, Durgude AG (2020) Effect of different irrigation and fertigation levels on yield and nutrient use efficiency in sweet orange (Citrus sinensis L. Osbeck) cv. Phule Mosambi. International Journal of Chemical Studies 8(3): 1577-1581.

Huang X, Huang HB, Gao F (2000) The growth potential generated in citrus fruit under water stress and its relevant mechanisms. Scientia Horticulturae 83: 227-240.

MAPM (2016) Ministère de l'agriculture et de la pêche maritime. Statistiques\&VeilleÉconomique - ministère de l'Agriculture.

Mota M, Pinto T, Vilela A, Marques T, Borges A, Caço J, FerreiraCardosoa J, Raimundo F, Gomes-Laranjo J (2018) Irrigation positively affects the chestnut's quality: The chemical composition, fruit size and sensory attributes. Scientia Horticulturae 238: 177-186.

Panigrahi P, Srivastava AK (2017) Water and nutrient management effects on water use and yield of drip irrigated citrus in vertisol under a sub-humid region. Journal of Integrative Agriculture 16: 1184-1194.

Panigrahi P, Srivastava AK, Huchche AD (2012) Effects of drip irrigation regimes and basin irrigation on Nagpur mandarin agronomical and physiological performance. Agriculture Water Management 104: 79-88.

Vijaya HM, Godara RK, Shashank S, Nidhi S (2017) Influence of different level of water and fertilizer application through drip system on growth and yield of kinnow mandarin (Citrus reticulata blanco). Journal of Experimental Biology and Agricultural Sciences 5(6): 840.845. 